\title{
Ocorrência de Lasiodiplodia pseudotheobromae em bacurizeiro (Platonia insignis)
}

\author{
Alessandra Keiko Nakasone ${ }^{1} \oplus$, Sandra Valéria Dias Cardoso $^{2} \oplus$, Ingrid Bernardo de Lima Coutinho ${ }^{1}$, \\ Kátia de Lima Nechet ${ }^{3}{ }^{\oplus}$, Solange da Cunha Ferreira ${ }^{2} \oplus$, Alessandra de Jesus Boari ${ }^{1} \oplus$, \\ Walnice Maria Oliveira Nascimento ${ }^{1} \mathbb{C}$, José Edmar Urano de Carvalho ${ }^{1} \mathbb{B}$
}

${ }^{1}$ Embrapa Amazônia Oriental, Tv. Dr. Enéas Pinheiro s/n, 66095-903, Belém-PA, Brasil; ${ }^{2}$ Universidade Federal Rural da Amazônia, Av. Perimetral, 2501, 66077-830, Belém-PA, Brasil; ${ }^{3}$ Embrapa Meio Ambiente, SP 340, km 127,5, CP 69, 13918-110, Jaguariúna-SP, Brasil.

Autor para correspondência: Alessandra Keiko Nakasone (alessandra.nakasone@embrapa.br)

Data de chegada: 20/03/2018. Aceito para publicação em: 23/01/2020.

$10.1590 / 0100-5405 / 193189$

O bacurizeiro (Platonia insignis Mart.) é espécie frutífera nativa da Amazônia com potencial de comercialização para todas as regiões do Brasil. No ano de 2012, observou-se a ocorrência de plantas com sintomas de seca descendente e exsudação de resina (Figura 1A, B) no Campo Experimental da Embrapa Amazônia Oriental em Belém, Pará. As plantas sintomáticas foram coletadas e transportadas ao Laboratório de Fitopatologia, onde foram realizados os procedimentos para a identificação do patógeno. Após o isolamento e cultivo em meio de cultura batata-dextrose-ágar (BDA), foi realizado o teste de patogenicidade em mudas de bacurizeiro, por meio de sobreposição de disco micelial no caule, previamente ferido, e vedado com parafilme.
Após oito dias da inoculação, constataram-se, nas plantas inoculadas, os mesmos sintomas de seca observados em campo (Figura 1C). O fungo foi reisolado e a patogenicidade comprovada. $\mathrm{O}$ isolado apresentou conídios hialinos, unicelulares, elipsoides que com o amadurecimento se tornavam marrom escuro, com parede espessa e septo centralizado e, algumas estrias longitudinais foram observadas (Figura 1D). O tamanho dos conídios variou de 23-26 $\mu \mathrm{m} \times 10-15 \mu \mathrm{m}(\mathrm{n}=30)$. A morfologia é característica do gênero fúngico Lasiodiplodia. Para a caracterização molecular, o DNA foi extraído a partir da colônia do fungo em meio de cultura BDA por sete dias (5). Posteriormente, realizou-se PCR utilizando os pares de primers: ITS4 e ITS5 (14), referentes à região
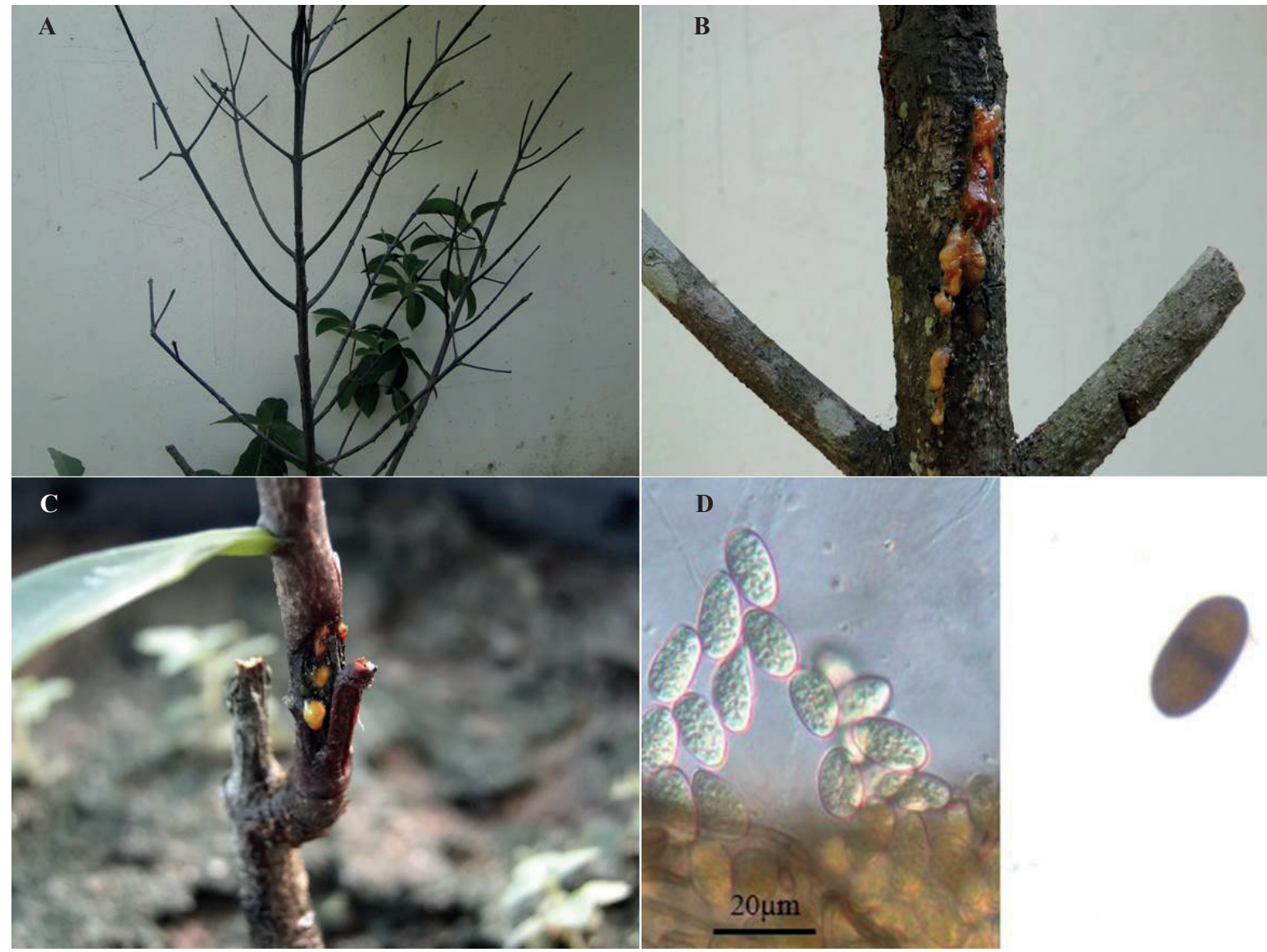

D
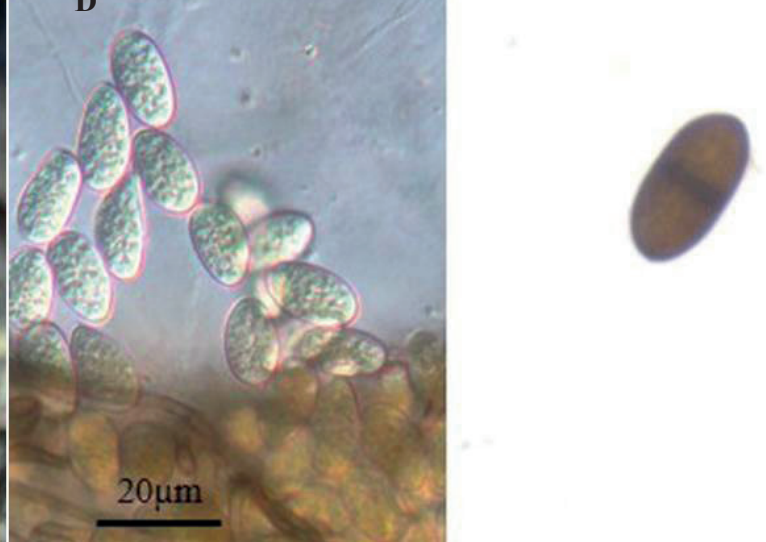

Figura 1. Sintomas da seca descendente (A) com a liberação de resina (B) em planta de bacurizeiro. Reação de muda de bacurizeiro nove dias após a inoculação de Lasiodiplodia pseudotheobromae (C). Conídios jovens (hialinos e unicelulares) e maduros com coloração escura e septo centralizado de L. pseudotheobromae (D) 
espaçadora transcrita interna (ITS), e EF1-688F e EF1-1251R (12), da região fator de elongação (EF1). Após amplificação do DNA, procedeu-se sua purificação e sequenciamento. As sequências ITS (KX171632) e EF1 (KX171633) obtidas foram comparadas com sequências disponíveis no GenBank via Blastn e citadas por Coutinho et al. (4), sendo posteriormente analisadas por meio de alinhamentos múltiplos através do programa ClustalW. As inferências filogenéticas para a verificação em nível de espécie foram aferidas por meio da análise de máxima parcimônia (MP) utilizando o método de busca heurística TBR no programa Mega X (7). A validade estatística da árvore foi testada usando análise de bootstrap com 1000 repetições. Um isolado de Macrophomina phaseolina (PD112) (6) foi usado como outgroup. Escores da árvore, incluindo seu comprimento, o índice de consistência (IC), índice de retenção (IR) e o índice de consistência redimensionada (CR) também foram calculados. As sequências obtidas foram depositadas no GenBank. A árvore mais parcimônia foi a de comprimento 498 ( $\mathrm{IC}=0,603104, \mathrm{IR}=0,848048$ e $\mathrm{CR}=543227)$. O isolado identificado formou clado com acessos de L. pseudotheobromae (CBS 116459 e CMM 3887) $(1,2,9)$ suportado por $89 \%$ de bootstrap. A informação presente nesse estudo é o primeiro relato de Lasiodiplodia pseudotheobromae causando seca descendente em bacurizeiro em território brasileiro. No Brasil, há relatos de L. pseudotheobromae ocorrendo em manga (10), mamão (2), mandioca (8), pinhão-manso (9), uva (3), coco (13), caqui (11), cajueiro, tamarindo e ciriguela (4). $\mathrm{O}$ isolado encontra-se depositado na Coleção de Microrganismos de Importância Agrícola e Ambiental da Embrapa Meio Ambiente, com o código CMAA1756.

\section{REFERÊNCIAS}

1. Alves, A.; Crous, P.W., Correia, A.;Phillips, A.J.L. Morphological and molecular data reveal cryptic speciation in Lasiodiplodia theobromae. Fungal Diversity, Kunming, v.28, p.1-13, 2008.

2. Brito Netto, M. S. B.; Assunção, I. P.; Lima, G.S.A. Species of Lasiodiplodia associated with papaya stem-end rot in Brasil. Fungal Diversity, New York, v. 67, p. $127-41,2014$.
3. Correia, K.; Silva, M. A.; De Morais, M. A.; Armengol, J.; Phillips, A. J. L.; Camara, M.P.S.; Michere, S. J. Phylogeny, distribution and pathogenicity of Lasiodiplodia species associated with dieback of table grape in the main Brazilian exporting region. Plant Pathology, Malden, v. 65, n. 1, p. 92-103, 2016.

4. Coutinho, I. B. L.; Freire, F. C. O.; Lima, C. S. ; Lima, J. S.; Gonçalves, F. J. T.; Machado, A. R.; Silva, A. M. S.; Cardoso, J. E. Diversity of genus Lasiodiplodia associated with perennial tropical fruit plants in northeastern Brazil. Plant Patholology, Malden, v. 66, p. 90-104, 2017.

5. Gibbs, A.; Mackenzie, A. A primer pair for amplifying part of the genome of all potyvirids by RT-PCR. Journal of virology methods, Amsterdam, v. 63 , p. 9-16, 1997.

6. Inderbitzin, P.; Bostock, R.M.; Trouillas, F.P.; Michailides, T.J. A six locus phylogeny reveals high species diversity in Botryosphaeriaceae from California almond. Mycologia, Lawrence,v.102, n.6, p.1350-1368, 2010.

7. Kumar, S.; Stecher, G.; Li, M.; Knyaz, C.; Tamura, K. MEGA X: Molecular Evolutionary Genetics Analysis across computing platforms. Molecular Biology and Evolution, Oxford, v.35, p.1547-1549. 2018.

8. Machado, A. R.; Pinho, D. B.; Oliveira, S. A. S.; Pereira, O. L. New occure rences of Botryosphaeriaceae causing black root rot of cassava in Brazil. Tropical Plant Pathology, Brasília, DF, v. 39, p. 464- 470, 2014.

9. Machado, A. R.; Pinho, D. B.; Pereira, O. L. Phylogeny, identification and pathogenicity of the Botryosphaeriaceae associated with collar and root rot of the biofuel plant Jatropha curcas in Brazil, with a description of new species of Lasiodiplodia. Fungal Diversity, New York, v. 67, p. 231-247, 2014.

10. Marques, M.W.; Lima, N.B.; Morais Junior, M.A.; Barbosa, M.A.G.; Souza, B.O.; Michereff, S. J.; Phillips, A. J. L.; Câmara, M. P.S. Species of Lasiodiplodia associated with mango in Brazil. Fungal Diversity, New York, v. 61, p. 181-193, 2013.

11. Nogueira Júnior, A. F.; Santos, R. F.; Pagenotto, A. C. V.; Spósito, M. B. First report of Lasiodiplodia pseudotheobromae causing fruit rot of persimmon in Brazil. New Disease Reports, London, v. 36, p. 1, 2017.

12. Phillips, A.; Alves, A.; Correia, A.; Luque, J. Two New Species of Botryosphaeria with Brown, 1-Septate Ascospores and Dothiorella Anamorphs. Mycologia, Lawrence, v. 97, n. 2, p. 513-529, 2005.

13. Rosado, A.W. C.; Machado, A. R.; Freire, F. C. O.; Pereira, O. L. Phylogy eny, identification and pathogenicity of Lasiodiplodia associated with postharvest stem-end of coconut in Brazil. Plant Disease, St. Paul, v. 100, n. 3, p. 561-568, 2016.

14. White, T. J.; Bruns, T.; Lee, S.; Taylor, J. Amplification and direct sequencing of fungal ribosomal RNA genes for phylogenetics. In: Innis, M. A.; Gelfand, D. H.; Sninsky, J. J.; White, T. J. (Ed.). PCR Protocols a guide to methods and applications. London: Academic Press, 1990. p. 315-322. 